\title{
Opinion \\ HIV the best thing to happen to me!
}

Volume 5 Issue 3 - 2017

\section{Opinion}

\section{About me}

I am Charlie, a 51-year-old African-American male HIV survivor. I was diagnosed in 2005 and have been taking control on my life ever since then. I know this may sound crazy but HIV is the best thing to ever happen to me. I was not in control of any aspect of my life. I went through life dealing with what life threw at me. I never once considered that I was the master of my own fate. I came from a family of farm and labor workers. I wanted to go to college but the mental abuse I suffered from the older generation in my family made college a dream and not the reality I wanted.

I was never sick, the only time I remember having to see a doctor was when I accidentally cut my finger and had to get stitches. Other than that, one incident, I had a perfect attendance from grade school through to high school. I was an adult when I first got the flu, I was in my early twenties in fact. It was amazing, flawless skin, great health, athletic, artistic my life was fantastic or so I thought.

\section{Personal Virus Encounter}

My first encounter with HIV and AIDS happened in the late 80's when I moved to Jacksonville Fla. I met several people there living with the virus and managing it very well. I had one friend that dies within days of finding out his status. I never had any problems with individuals living with the virus but many other, that I have personally witnessed, mistreated, outed and ostracized them incisively. I had even volunteered to help people living with the virus get the services and care they needed. I never realized that while I was helping and volunteering that I was in fact infected myself. I never went to the doctor but one time in my life and that was when I accidently cut my finger at the age of 15 if I remember correctly.

Fast forward, January 2005, I was working two jobs to support my family and help out other family members struggling for one reason or another. I used marijuana and crack cocaine to help cope with the harsh realities that confronting me every day. I was a functioning addict. I held a management position at a popular restaurant. I was doing well, or so I thought. One day I slipped and fell at work. From that, I was unable to work and had all kinds of physical problems. First, I could not eat anything I normally ate. Fruits were what I lived on when I did not want to eat anything else. Oranges were my best friend; I could no longer ingest them. Eggs my staple food, late night snack, bacon egg, and cheese, no longer an option.

All the medications, they gave me I was very allergic to, noproxy sodium made my skin peels from my body like a burn or something it was horrible. None of the doctors I consulted, and they were many, never administered an STD panel, not one. I was vomiting what looked like coffee grounds. I lost over $40 \mathrm{lbs}$. twice. I went from weighing almost 180 pounds to weighing just a little over 100 pounds. I lost so much weight my underwear would fall off me. I was in bad shape for a long time.

During this period of hardship, I went to county jail for a crime; I did not commit. However, this incarceration is what saved my life.

\author{
Charlie Walter Gorham \\ Computer Information Systems Consultant, USA
}

Correspondence: Charlie Walter Gorham, Computer Information Systems Consultant, PETS Counselor, Playwright, HIV Survivor, Jacksonville, North Carolina, USA, Email scimond@aol.com

Received: March 23, 2017| Published: April 04, 2017

During this time, I was itching very badly, scratching holes in my skin, I had breakouts all over my body that once was blemish free. I was hot all the time, and I could barely eat enough to sustain an ant. Once in jail, the nurse there looked me and told me I was HIV positive and asked me to take the STD panel test which I conceded. One my birthday, February 8th, 2005, I found out I had AIDS, not HIV....AIDS.

It was hard, but I made it through, and once out I consulted the Community Based organization for help with finding and securing a physician. Betsy Richard was my first HIV doctor. She was very nonchalant about it, which made me very uncomfortable and unassured that I would live. I was weak, hot, itchy, scared, upset, hungry, tired and many more things that affected my everyday living. Not being able to work and suffering from all kinds of depressions, anxieties, and delusions about the virus, I begin my quest to search out everything about the virus I could find.

The mental health specialist I was seeing asked me to sit in on a couple of meetings with clients that have been living with the virus so that I could see that it was possible to live a long healthy life and still have a life in the process. I did, and everything changed. I began volunteering again with the Case Management Service I was a patron. I became a member of the Eastern Carolina HIV and AIDS Partnership Consortium ECHAP which is now defunct due to changes in HIV and AIDS laws and service merchants. I have done outreach programs for Migrant workers and have also held programs for the community to educate them on HIV and AIDS. I have done testing's, speaking engagements throughout the community and in different states. I become a board member for the Carolina Family Health Care Center, hold two positions.

\section{Living with HIV}

Shortly after that in 2007, I went back to school, a community college ECC in fact, and got an AAS in Computer Information Technology. I went to a four-year institution NCWC to obtain my 
BS in the same field and is currently in graduate school pursuing an MBA in Computer Information Security. I have been managing this virus since 2005. I have had three medication modification first from Truvada and Sustiva to Atripla and Atripla back to Truvada and another drug I cannot remember because the Atripla stopped working for me. Now I am on Trumeg with is doing great so far.

Today I am living with HIV, and it is still hard to get up and take those seven pills every day. I do not like medications period but to live, I must adhere to the doctor's orders. My life is manageable, and it does still affect me daily, but it is a necessary happenstance that I must conform to remain undetectable.

\section{Acknowledgments}

None.

\section{Conflicts of interest}

None. 